Article

\title{
Design of p-n homojunctions in metal-free carbon nitride photocatalyst for overall water splitting
}

\author{
Gang Zhao a, ${ }^{\text {† }}$, Shuhua Hao a ${ }^{\text {, }}$, Jinghua Guo a, Yupeng Xing a Lei Zhang b, Xijin Xu a,* \\ a Laboratory of Functional Micro-nano Material and Device, School of Physics and Technology, University of Jinan, Jinan 250022, Shandong, China \\ b State Key Lab of Crystal Materials, Shandong University, Jinan 250100, Shandong, China
}

A R T I C L E I N F O

Article history:

Received 21 May 2020

Accepted 27 June 2020

Published 5 March 2021

\section{Keywords:}

2D Metal-free photocatalyst

Carbon nitride

Overall water splitting

Time-resolved photoluminescence

spectra

Density-functional theory

Heterogeneous structure

\begin{abstract}
A B S T R A C T
Two-dimensional (2D) carbon nitride (CN) photocatalysts are attracting extensive attention owing to their excellent photocatalytic properties. In this study, we successfully prepared $\mathrm{CN}$ materials with heterogeneous structures via hydrothermal treatment, high-temperature roasting, ball milling, sintering, and other processes. Benefitting from interface interactions in hybrid architectures, the CN photocatalysts exhibited high photocatalytic activity. The rate of hydrogen production using these $\mathrm{CN}$ photocatalysts reached $17028.82 \mu \mathrm{mol} \mathrm{h}^{-1} \mathrm{~g}^{-1}$, and the apparent quantum efficiency was $11.2 \%$ at $420 \mathrm{~nm}$. The ns-level time-resolved photoluminescence (PL) spectra provided information about the time-averaged lifetime of fluorescence charge carriers; the lifetime of the charge carriers causing the fluorescence of $\mathrm{CN}$ reached $9.99 \mathrm{~ns}$. Significantly, the $\mathrm{CN}$ photocatalysts displayed satisfactory results in overall water splitting without the addition of sacrificial agents. The average hydrogen and oxygen production rates were $270.95 \mu \mathrm{mol} \mathrm{h}^{-1} \mathrm{~g}^{-1}$ and $115.21 \mu \mathrm{mol} \mathrm{h}^{-1} \mathrm{~g}^{-1}$ in $7 \mathrm{~h}$, respectively, which were promising results for the applications of the catalysts in overall water splitting processes. We investigated the high efficiency of the prepared $\mathrm{CN}$ photocatalysts via a series of tests (UV-vis diffuse reflectance spectroscopy, photocurrent response measurements, PL emission spectroscopy, time-resolved PL spectroscopy, and Brunauer-Emmett-Teller analysis). Furthermore, the Mott-Schottky plot and current-voltage curve were acquired via electrochemical tests. The fabricated $\mathrm{CN}$ photocatalyst had a small p-n junction in its heterogeneous structure, which further enhanced its photocatalytic efficiency. Therefore, this work can promote the development of CN photocatalysts.
\end{abstract}

(C) 2021, Dalian Institute of Chemical Physics, Chinese Academy of Sciences. Published by Elsevier B.V. All rights reserved.

\section{Introduction}

Two-dimensional (2D) graphene-like carbon nitride (CN) photocatalysts have been recently receiving significant attention from researchers owing to their particularly good response to visible light, relatively large specific surface area, non-toxicity, low cost, and other advantages [1-10]. In 2009,
Wang et. al [11] successfully used block g- $\mathrm{C}_{3} \mathrm{~N}_{4}$ as a photocatalyst in water splitting for the production of hydrogen. Subsequently, high-quality $\mathrm{g}-\mathrm{C}_{3} \mathrm{~N}_{4}$ or composite structures (metallic oxide/g- $\mathrm{C}_{3} \mathrm{~N}_{4}$ ) were prepared via various methods [12-17]. For example, She et al. designed $\alpha-\mathrm{Fe}_{2} \mathrm{O}_{3}$ nanosheets that could actively promote the exfoliation of $\mathrm{g}-\mathrm{C}_{3} \mathrm{~N}_{4}$, producing $2 \mathrm{D}$ hybrid structures that exhibited good photocatalytic efficiency in the

\footnotetext{
*Corresponding author. Tel/Fax: +86-531-82769995; E-mail: sps_xuxj@ujn.edu.cn

† These authors contributed equally to this work.

This work was supported by the National Natural Science Foundation of China $(51802177,51672109,11504134)$, the Major Basic Program of the Natural Science Foundation of Shandong Province (ZR2018ZC0842), and Natural Science Foundation of Shandong Province (ZR2018BEM019). DOI: 10.1016/S1872-2067(20)63670-1 | http://www.sciencedirect.com/science/journal/18722067 | Chin. J. Catal., Vol. 42, No. 3, March 2021
} 
production of hydrogen [18]. All these reports showed that g- $\mathrm{C}_{3} \mathrm{~N}_{4}$ had numerous application prospects in the field of water splitting.

However, there are two difficulties encountered during the production of hydrogen. The first is that, like metal-free $\mathrm{CN}$ photocatalysts, metal-based composite $\mathrm{CN}$ materials are often prepared [19-27]. The second is the need to add a sacrificial agent in water splitting; otherwise, the effect of the catalyst is extremely low [28-33]. Therefore, these two issues limit the practical applications of $\mathrm{CN}$ to metal-free photocatalysts. In 2015, Kang's research group used carbon quantum dots with $\mathrm{CN}$ to conduct a full splitting water experiment via an all-metal-free photocatalyst without the use of precious metals and sacrificial agents for the first time; they proposed the two-electron channel phenomenon in Science [34]. Since then, there have been few major breakthroughs in the use of metal-free $\mathrm{CN}$ photocatalysts for the full splitting of water.

In our previous work, we investigated a lot of literature on $\mathrm{CN}$. We found that almost all CN photocatalysts assumed n-type structures owing to specific ratios of carbon and nitrogen [35-41]. Generally, most researchers use p-type metal-based materials and n-type $\mathrm{CN}$ photocatalysts for the development of composites, which was inspired by the fundamental p-n junction principle applied in silicon solar cells. This structure can greatly improve the light-conversion efficiency of hybrid photocatalysts. For example, Sun et al. reported that a $\mathrm{ZnO} / \mathrm{g}-\mathrm{C}_{3} \mathrm{~N}_{4}$ composite photocatalyst exhibited better photocatalytic activity than pure g- $\mathrm{C}_{3} \mathrm{~N}_{4}$ [42]. However, the synthesis of p-type metal-free $\mathrm{CN}$ photocatalysts has rarely been reported. Therefore, we aimed to design a metal-free $\mathrm{CN}$ photocatalyst with a small p-n junction structure.

Recently, we prepared a new 2D CN-precursor organic material with a thickness of approximately $1 \mathrm{~nm}$ [43]. The carbon content of the prepared $\mathrm{CN}$ was higher than the nitrogen content, and the prepared material was a p-type $\mathrm{CN}$ semiconductor [43]. Thus, the prepared material could be compounded with conventional n-type $\mathrm{CN}$ semiconductor materials. A pure metal-free $\mathrm{CN}$ photocatalyst had a heterogeneous structure with a small p-n junction and was prepared after grinding and calcining. This type of non-metallic CN photocatalyst displayed superior photocatalytic effect (hydrogen production rate of $17028.82 \mu \mathrm{mol} \mathrm{h}-1 \mathrm{~g}^{-1}$ ) than other pure CN photocatalysts under the same experimental conditions. The apparent quantum efficiency (AQE) was $11.2 \%$ at $420 \mathrm{~nm}$. The ns-level time-resolved photoluminescence (PL) spectra provided information about the time-averaged lifetime of fluorescence charge carriers; the lifetime of the charge carriers causing the fluorescence of CN reached 9.99 ns. Significantly, the CN photocatalyst demonstrated satisfactory results in overall water splitting without the addition of sacrificial agents (the average hydrogen and oxygen production rates were $270.95 \mu \mathrm{mol} \mathrm{h}^{-1}$ $\mathrm{g}^{-1}$ and $115.21 \mu \mathrm{mol} \mathrm{h}{ }^{-1} \mathrm{~g}^{-1}$, respectively, within the first $7 \mathrm{~h}$ ).

We investigated the high efficiency of this $\mathrm{CN}$ photocatalyst via a series of tests (UV-vis diffuse reflectance spectroscopy, photocurrent response measurements, PL emission spectroscopy, time-resolved PL spectroscopy, and Brunauer-Emmett-Teller (BET) analysis). Furthermore, the
Mott-Schottky plot and current-voltage curve were acquired via electrochemical tests. The fabricated $\mathrm{CN}$ photocatalyst had a small p-n junction in its heterogeneous structure, which further enhanced its photocatalytic efficiency. Therefore, this work can promote the development of $\mathrm{CN}$ photocatalysts.

\section{Experimental}

\subsection{Preparation}

Analytical-grade ammonium fluoride, melamine, triethanolamine, and alcohol were purchased from Sinopharm Chemical Reagent Co. Ltd. (Shanghai). All reagents were used as received.

First, $5 \mathrm{~g}$ melamine as the raw material was heat-treated via hydrothermal synthesis at $180{ }^{\circ} \mathrm{C}$ for $24 \mathrm{~h}$, filtered, and dried. Then, the material was transferred into a tubular furnace under the protection of high-purity argon at $550{ }^{\circ} \mathrm{C}$ for $1 \mathrm{~h}$. Second, $5 \mathrm{~g}$ melamine was treated with $5 \mathrm{~g}$ ammonium fluoride at $180{ }^{\circ} \mathrm{C}$ for $24 \mathrm{~h}$, filtered, and dried. The product was heat-treated in a tubular furnace under a protective nitrogen atmosphere at 550 ${ }^{\circ} \mathrm{C}$ for $1 \mathrm{~h}$. Finally, we mixed two types of $\mathrm{CN}$ in equal proportions, grinded them, and transferred them to the tube furnace for quenching at $550{ }^{\circ} \mathrm{C}$ for $1 \mathrm{~h}$ at a heating rate of $5{ }^{\circ} \mathrm{C} / \mathrm{min}$ (the protective gas was nitrogen). Then, the target material (CN) could be synthesized. The bulk melamine raw material was directly treated for $2 \mathrm{~h}$ in air at $550{ }^{\circ} \mathrm{C}$ in a contrast experiment.

\subsection{Measurement of hydrogen and oxygen evolution}

The photocatalytic reactions were carried out in a Pyrex reaction cell connected to a closed gas-circulation and evacuation system: (a) $0.05 \mathrm{~g}$ catalyst (1\% Pt) was dispersed in $100 \mathrm{~mL}$ aqueous solution containing $20 \mathrm{~mL}$ triethanolamine as a sacrificial agent. Then, the suspension was thoroughly degassed and irradiated using a Xe lamp (300 W) equipped with an optical cut-off filter $(\lambda>420 \mathrm{~nm})$ to eliminate ultraviolet light. The temperature of the reactant solution was maintained at $279 \mathrm{~K}$ by flowing cooling water during the reaction. The amount of $\mathrm{H}_{2}$ produced was analyzed using an online gas chromatograph. The activities of different catalysts were compared using the average rate of $\mathrm{H}_{2}$ evolution in the first $7 \mathrm{~h}$. The AQE was also measured under similar conditions using the following equation: $\mathrm{AQE}=2 \times$ amount of hydrogen molecules evolved/number of incident photons $\times 100 \%$. (b) $0.05 \mathrm{~g}$ catalyst $(1 \% \mathrm{Pt})$ was dispersed in $100 \mathrm{~mL}$ aqueous solution. Then, the suspension was thoroughly degassed and irradiated using a Xe lamp $(300 \mathrm{~W})$ to eliminate ultraviolet light. The temperature of the reactant solution was maintained at $279 \mathrm{~K}$ by flowing cooling water during the reaction. The amount of $\mathrm{H}_{2}$ and $\mathrm{O}_{2}$ produced was analyzed using an online gas chromatograph.

\subsection{Photoelectrochemical activity measurements}

Photoelectrochemical test systems included a CHI660D workstation (Shanghai Chenhua, China) with a three-electrode configuration using the prepared samples as the working elec- 
trodes, a Pt plate as the counter electrode, $\mathrm{Ag} / \mathrm{AgCl}$ as the reference electrode, and a 300-W Xe lamp equipped with an optical cut-off filter $(\lambda>420 \mathrm{~nm})$ as the light source. $\mathrm{Na}_{2} \mathrm{SO}_{4}$ was used as the electrolyte in an aqueous solution $(0.5 \mathrm{M})$. The working electrodes were prepared as follows: $10 \mathrm{mg}$ of the as-prepared $\mathrm{CN}$ was dispersed in absolute ethanol and the suspension was directly deposited onto a fluorine-doped tin oxide conductive glass plate and dried at $80{ }^{\circ} \mathrm{C}$ in a vacuum oven.

\subsection{Material Characterization}

Scanning electron microscopy (SEM) was performed with a Hitachi S-4800 microscope. Fourier-transform infrared spectroscopy was carried out with a Thermo-Nicolet Nexus 670 infrared (IR) spectrometer. X-ray diffraction (XRD) patterns were recorded on a Bruker D8 Advance powder X-ray diffractometer using $\mathrm{Cu} K_{\alpha}$ radiation $(\lambda=0.15406 \mathrm{~nm})$. UV-vis diffuse reflectance spectra were recorded on a Shimadzu UV-2550 spectrophotometer within a wavelength range of $300 \mathrm{~nm}$ to $800 \mathrm{~nm}$. The PL spectra of the photocatalysts were recorded using an Edinburgh FLS920 spectrometer. X-ray photoelectron (XPS) measurements were carried out using the Thermo Fisher ESCALAB 250 monochromatized XPS spectrometer with Al $(K \alpha)$ radiation as the probe and a $500-\mathrm{mm}$ analysis spot size. The pressure of the base chamber was $2 \times 10^{-9}$ mbar.

\subsection{Theoretical analysis}

We performed first-principles density-functional (DFT) theory calculations using the Vienna ab initio simulation package. The energy cut-off of the plane-wave basis set was $500 \mathrm{eV}$. A generalized gradient approximation in the form of Perdew-Burke-Ernzerhof for the electron exchange-correlation functional was employed to optimize the structure. The unit cell was repeated periodically along the $x$ - and $y$-directions, while a vacuum space of approximately $15 \AA$ was applied along the z-direction to avoid interaction between adjacent images. In the static self-consistent calculations, we adopted a $10 \times 10 \times 1$ Monkhorst-Pack $k$-point mesh for Brillouin zone sampling. All the atoms were fully relaxed without symmetry restrictions until the residual forces on each atom were smaller than 0.01 $\mathrm{eV} / \mathrm{A}$.

\section{Results and discussion}

The flow diagram of the preparation of the $\mathrm{CN}$ photocatalyst with a heterogeneous structure is shown in Fig. 1. First, melamine was used as the raw material, and it was heat-treated under hydrothermal synthesis at $180^{\circ} \mathrm{C}$ for $24 \mathrm{~h}$, filtered, and dried. Then, the material was transferred into a tubular furnace under the protection of high-purity argon at $550{ }^{\circ} \mathrm{C}$ for $1 \mathrm{~h}$. Second, melamine was treated with ammonium fluoride at 180 ${ }^{\circ} \mathrm{C}$ for $24 \mathrm{~h}$, filtered, dried, and calcined (at $550{ }^{\circ} \mathrm{C}$ for $1 \mathrm{~h}$ ) leading to $\mathrm{CN}$. Finally, we mixed two types of $\mathrm{CN}$ in equal proportions, grinded them, and transferred them to the tube furnace for quenching at $550{ }^{\circ} \mathrm{C}$ for $1 \mathrm{~h}$. Then, the target material (CN)

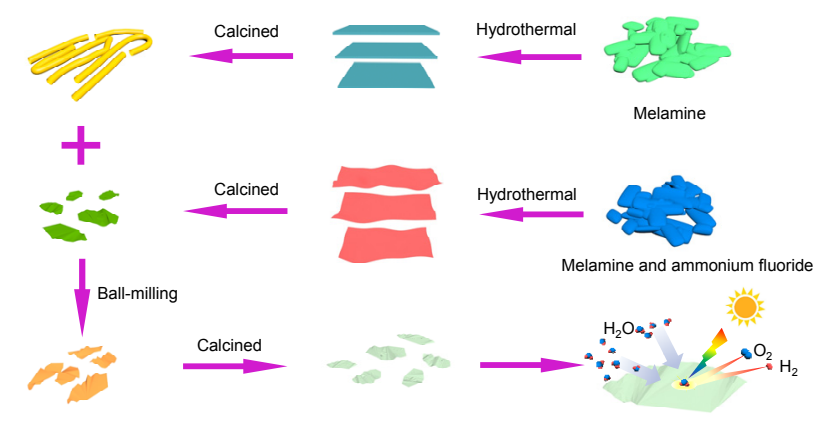

Fig. 1. Process flow diagram of the preparation of $\mathrm{CN}$ photocatalyst with a heterogeneous structure.

could be synthesized.

The morphology of different CN photocatalysts was observed via SEM. The nanotube-like type CN shown in Fig. 2(a) was synthesized based on the above method. The maximum length of the nanotubes was approximately $6 \mu \mathrm{m}$, and most of the nanotubes were distorted at high temperatures. The surface morphology of another type of $\mathrm{CN}$, prepared via the second method mentioned above, is displayed in Fig. 2(b); the nanosheets exhibited a degree of distortion. The chiffon CN nanosheet is visible in the lower right corner of Fig. 2(b). When the two types of $\mathrm{CN}$ were mixed, ground, and roasted, lamellar $\mathrm{CN}$ with a heterogeneous structure was formed, as shown in Fig. 2(c). For comparison, ordinary g- $\mathrm{C}_{3} \mathrm{~N}_{4}$ was prepared according to previous reports [44-49]. The block and unordered structure of ordinary g- $\mathrm{C}_{3} \mathrm{~N}_{4}$ is shown in Fig. 2(d).

The IR spectra and XRD patterns of the photocatalysts are shown in Fig. 2(e) and 2(f). The IR spectra and XRD patterns of the three types of $\mathrm{CN}$ were very similar despite their varying shapes. The $\mathrm{CN}$ nanotubes had a weak $\mathrm{N}-\mathrm{H}$ bond because the content of the $\mathrm{NH}_{3}$ group in the sample was very low after water heat treatment (3000-3500 $\mathrm{cm}^{-1}$ ) (Fig. 2(e)) [44-46]. The peaks at $1000-1450 \mathrm{~cm}^{-1}$ were caused by $\mathrm{C}-\mathrm{N}$ stretching vibrations and the spectra of all three types of $\mathrm{CN}$ contained the same absorption peak. The peaks of the $\mathrm{CN}$ nanosheets at 1500-1700 $\mathrm{cm}^{-1}$ were different from the absorption peaks of other samples ( $\mathrm{CN}$ nanotubes and this work-CN). This was because there were more $\mathrm{C}-\mathrm{C}$ than $\mathrm{C}-\mathrm{N}$ bonds in the $\mathrm{CN}$ nanosheets. Furthermore, the peak at $809 \mathrm{~cm}^{-1}$ was ascribed to the vibrational fingerprint of the $\mathrm{C}-\mathrm{NH}-\mathrm{C}$ units in the three types of CN [47-49]. The XRD patterns of the samples (Fig. 2(f)) showed that the peaks of the prepared $\mathrm{CN}$ nanosheets were different from those of the $\mathrm{CN}$ nanotubes and this work-CN because the $\mathrm{CN}$ nanosheets had fluorine ions in their structure. High-resolution XPS spectra of F1s are displayed in Fig. S1. Fluoride was present in the CN nanosheet and the amount of fluorine in the final product was so small that the XPS test could not detect it. The (002) and (001) crystal facets of the three types of $\mathrm{CN}$ were similar to those of $\mathrm{CN}_{x}$ (No. JCPDS 50-0664) from the bulk melamine raw material $[50,51]$.

The yield and efficiency of the photocatalytic water splitting into hydrogen and oxygen under visible-light irradiation were 

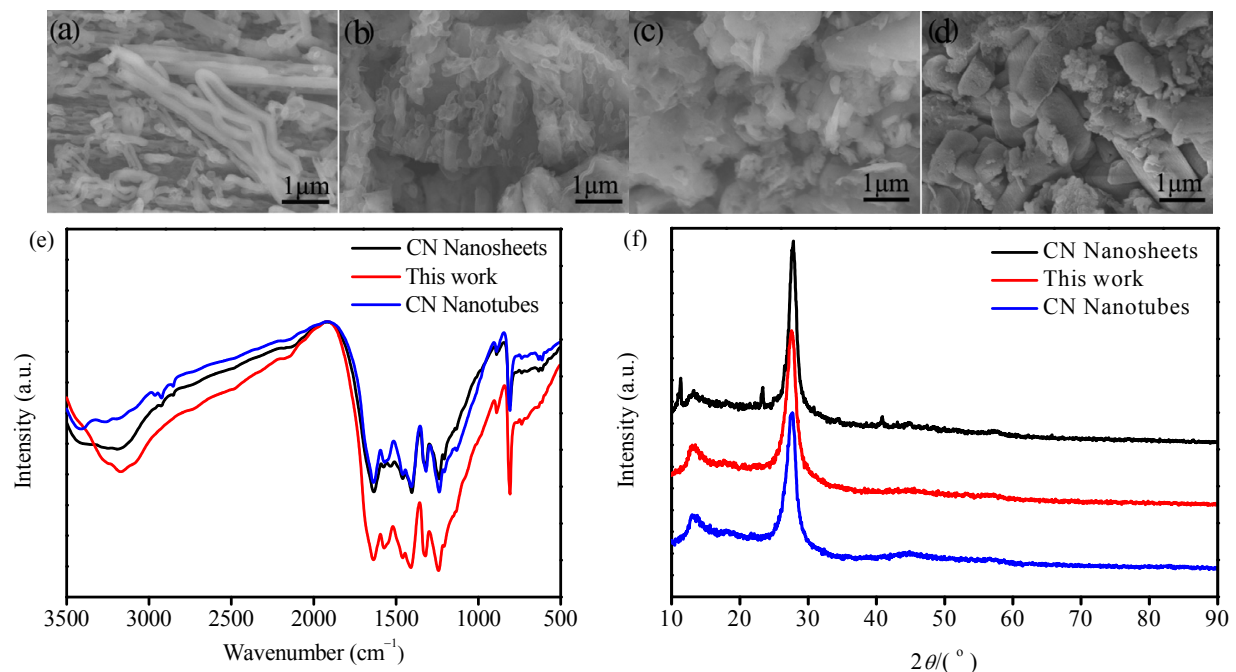

Fig. 2. SEM images of CN nanotubes (a), CN nanosheets (b), CN photocatalyst (c) with heterogeneous structure, and ordinary g- $\mathrm{C}_{3} \mathrm{~N}_{4}$ photocatalyst (d); IR spectra (e) and XRD patterns (f) of photocatalysts.

used to evaluate the catalytic performance, as shown in Fig. 3. The efficiency of this work-CN catalyst in hydrogen evolution was much higher than those of the $\mathrm{CN}$ nanotubes, $\mathrm{CN}$ nanosheets, and $\mathrm{g}-\mathrm{C}_{3} \mathrm{~N}_{4}$ catalyst (Fig. 3(a)). Furthermore, the hydrogen-evolution rate of this work-CN was approximately $17028.82 \mu \mathrm{mol} \mathrm{h}^{-1} \mathrm{~g}^{-1}$ (Fig. 3(b)), and it was much higher than those of other $\mathrm{CN}$ photocatalysts under the same experimental conditions. Moreover, the $\mathrm{AQE}$ of this work-CN was $11.2 \%$, $3.18 \%$, and $0.23 \%$ at 420,475 , and $550 \mathrm{~nm}$, respectively (Fig. $3(\mathrm{c})$ ). The AQE value of $11.2 \%$ at $420 \mathrm{~nm}$ was satisfactory. Furthermore, the $\mathrm{CN}$ catalyst demonstrated good overall water splitting capability without the addition of sacrificial agents. The hydrogen and oxygen production rates were 270.95 and $115.21 \mu \mathrm{mol} \mathrm{h}^{-1} \mathrm{~g}^{-1}$, respectively, within the first $7 \mathrm{~h}$ (Fig. 3(d) and $3(\mathrm{e}))$.

To evaluate the efficiency of this work-CN in photocatalytic hydrogen and oxygen production, the reaction was allowed to proceed for $70 \mathrm{~h}$ with intermittent evacuation every $7 \mathrm{~h}$, as shown in Fig. 3(f). Continuous $\mathrm{H}_{2}$ and $\mathrm{O}_{2}$ evolution by $\mathrm{CN}$ was observed from the beginning of the reaction. The total evolution of $\mathrm{H}_{2}$ and $\mathrm{O}_{2}$ after $70 \mathrm{~h}$ was 12131 and $4895 \mu$ mol, respectively. The average hydrogen and oxygen production rates were 173.30 and $69.93 \mu \mathrm{mol} \mathrm{h}^{-1} \mathrm{~g}^{-1}$ in $70 \mathrm{~h}$, respectively. Although the overall water splitting efficiency was lower than that of the first cycle (first $7 \mathrm{~h}$ ), the 70 -h average efficiency was significantly higher than those of the first cycle reported previously [34]. The decrease in the efficiency was due to the photocorrosion of the photocatalyst by simulated sunlight, which
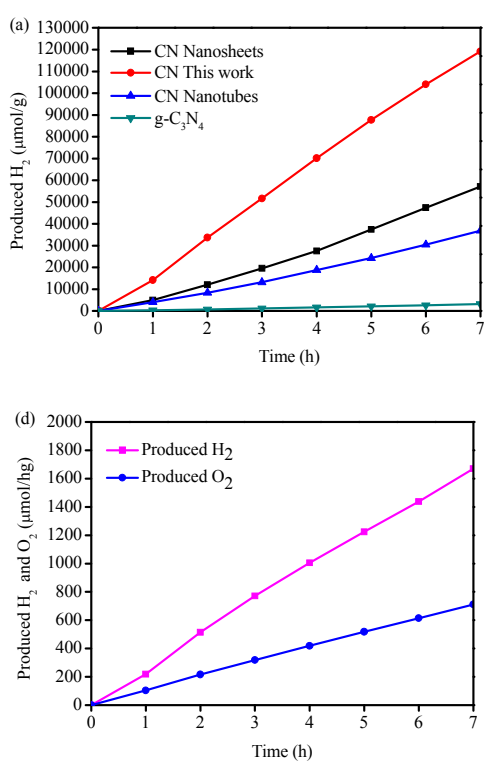
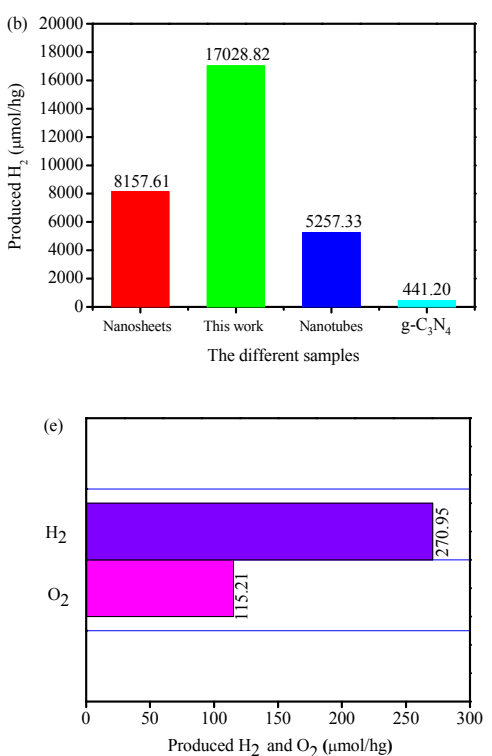
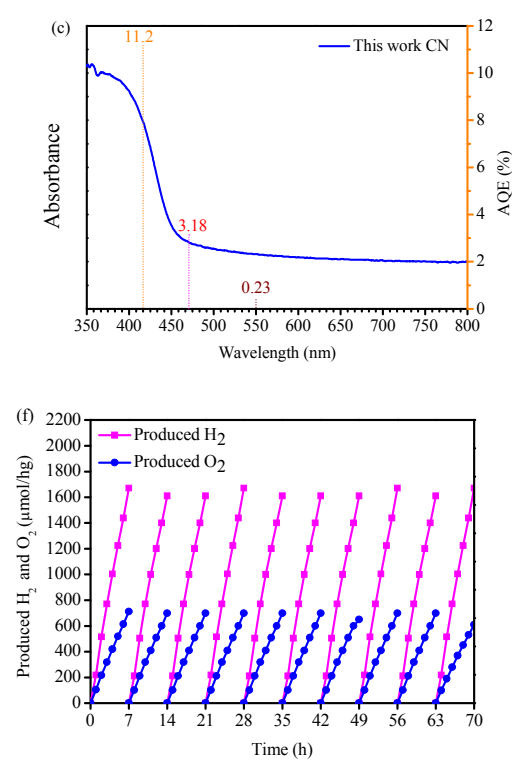

Fig. 3. (a) Typical time course of $\mathrm{H}_{2}$ production from aqueous solution (100 mL) containing triethanolamine (20 vol\%) as a sacrificial electron donor and $50 \mathrm{mg}$ of $1 \mathrm{wt} \%$ Pt-loaded catalyst under $300 \mathrm{~W}$ Xe lamp with an optical cut-off filter $(\lambda>420 \mathrm{~nm})$; (b) Hydrogen evolution rates with different CN photocatalysts; (c) Wavelength dependent $\mathrm{AQE}$ by this work-CN; (d) $\mathrm{H}_{2}$ and $\mathrm{O}_{2}$ production from aqueous solution (100 mL) and $50 \mathrm{mg}$ of $1 \mathrm{wt} \%$ Pt-loaded catalyst under $300 \mathrm{~W}$ Xe lamp; (e) $\mathrm{H}_{2}$ and $\mathrm{O}_{2}$ evolution rates based on this work-CN photocatalyst; (f) $\mathrm{H}_{2}$ and $\mathrm{O}_{2}$ evolution cycling curves of this work-CN photocatalyst. 

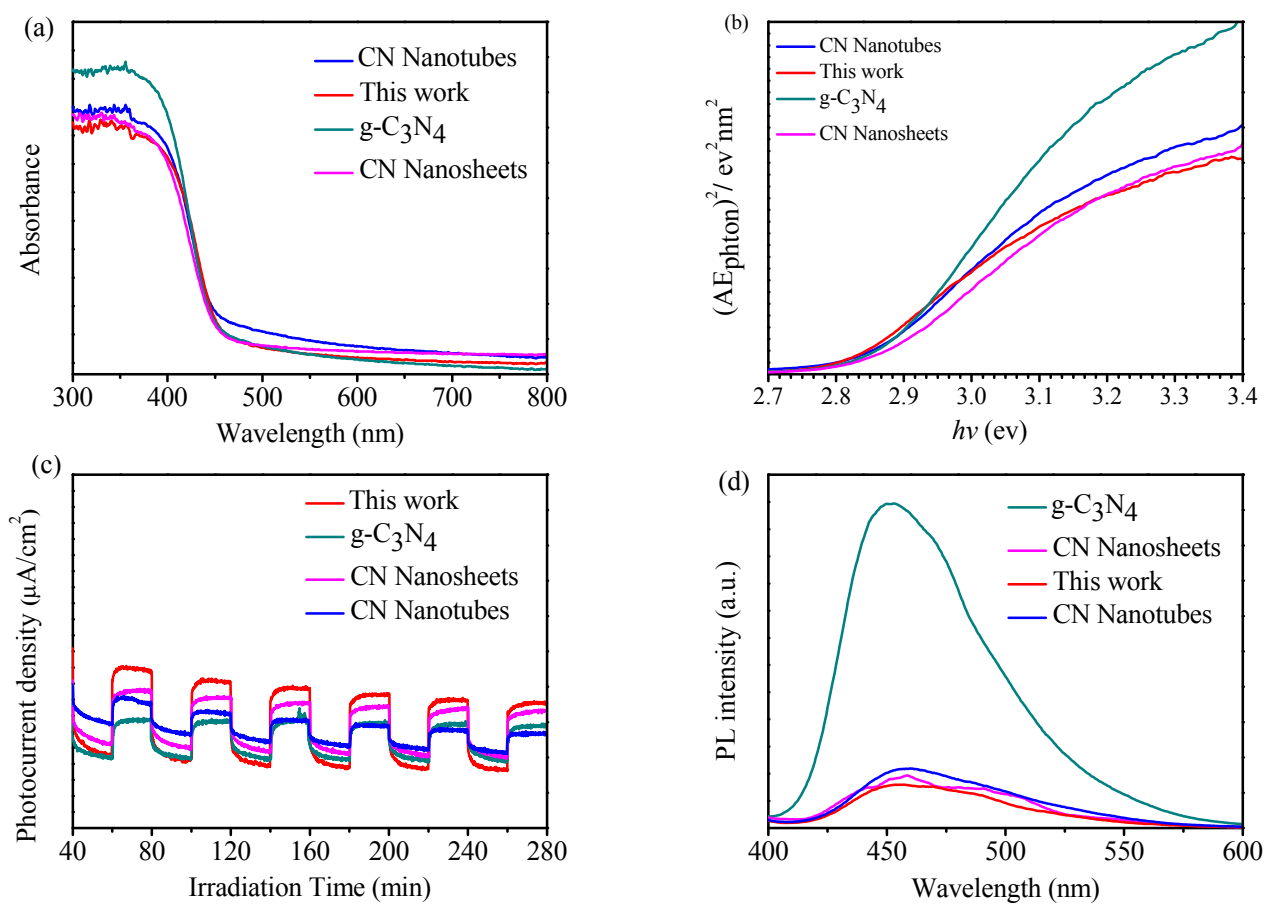

Fig. 4. (a) UV-vis diffuse reflectance spectra of different CN photocatalysts; (b) Plot of (AEphoton) ${ }^{2} \sim$ Ephoton; (c) Photocurrent response of samples to on-off cycles of illumination; (d) PL emission spectra.

was a problem with all photocatalysts and remains to be studied.

The optical absorptions of $\mathrm{CN}$ photocatalysts were analyzed via UV-vis, photocurrent response, and PL measurements, as depicted in Fig. 4. The band edges of different CN photocatalysts were positioned at approximately 435-450 nm (Fig. 4(a)). The absorption edges energy was $2.75-2.85 \mathrm{eV}$, as shown in Fig. 4(b). The $E_{\mathrm{g}}$ values of this work-CN, CN nanotubes, CN nanosheets, and g- $\mathrm{C}_{3} \mathrm{~N}_{4}$ were approximately $2.75,2.81,2.85$, and $2.83 \mathrm{eV}$, respectively. The photocurrent response was evaluated to measure the photogenerated electron-hole separation, as shown in Fig. 4(c) [52-54]. The transient photocurrent responses of different $\mathrm{CN}$ photocatalysts were recorded for several on-off cycles of irradiation. When simulated sunlight was shining, the photocurrent increased sharply, and it quickly returned to its dark current state when the light was turned off. As shown in Fig. 4(c), the photocurrents were stable and reproducible during several intermittent on-off irradiation cycles. The prepared CN exhibited satisfactory photocurrent response compared to $\mathrm{CN}$ nanotubes, $\mathrm{CN}$ nanosheets, and $\mathrm{g}-\mathrm{C}_{3} \mathrm{~N}_{4}$, indicating that the recombination of the photogenerated charge carriers was greatly inhibited by the heterogeneous structure. The PL spectra of different CN photocatalysts are shown in Fig. 4(d); the heterogeneous structure decreased the recombination of the electron-hole pairs in comparison with the structures of the other $\mathrm{CN}$ photocatalysts.

Furthermore, time-resolved PL spectra were recorded on an FLS980 fluorescence spectrometer (Edinburgh Instruments) with excitation at $420 \mathrm{~nm}$. The ns-level time-resolved PL spectra provided information about the time-averaged lifetime of fluorescence charge carriers (Fig. 5) [55-57]. The effective lifetime of charge carriers was 6.81 ns in the $\mathrm{CN}$-nanotubes photocatalyst at 450 under $420 \mathrm{~nm}$ excitation, and the effective lifetime of the $\mathrm{CN}$ nanosheets charge carriers was $7.98 \mathrm{~ns}$ (Figs. 5(a) and 5(b)). However, the lifetime of the charge carriers causing fluorescence in this work-CN reached 9.99 ns, as shown in Fig. 5(c). The lifetime of the charge carriers in these three CN materials was higher than that of previously reported block CN
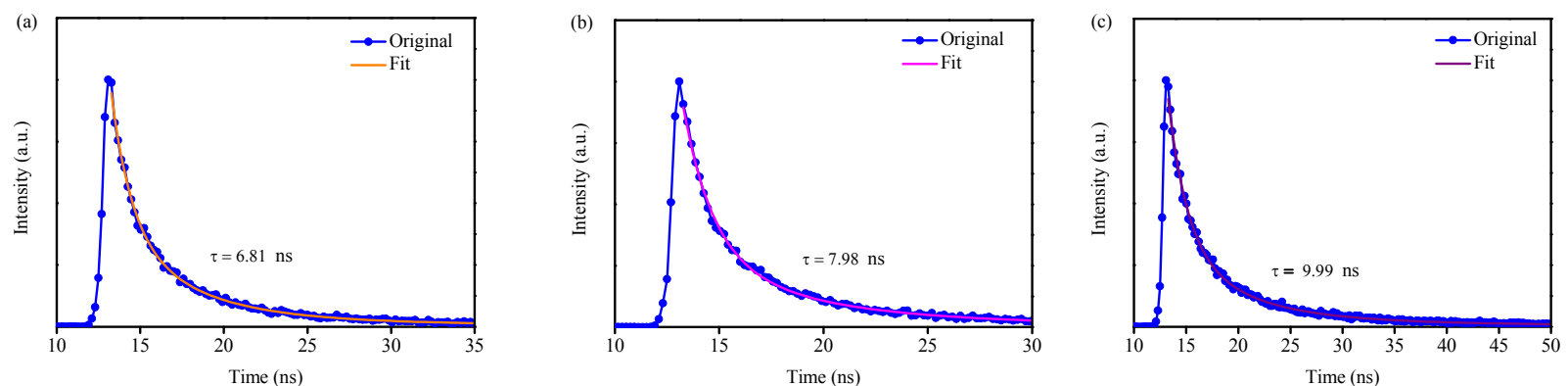

Fig. 5. ns-Level time-resolved PL spectra monitored at $450 \mathrm{~nm}$ under $420 \mathrm{~nm}$ excitation for CN nanotubes (a), CN nanosheets (b), and this work-CN (c). 

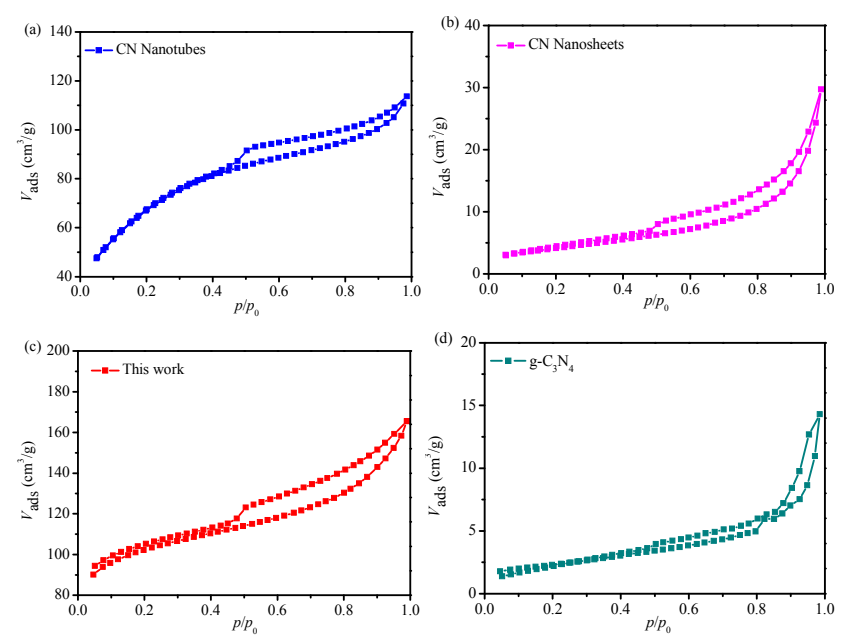

Fig. 6. Typical nitrogen adsorption-desorption isotherms of different $\mathrm{CN}$ photocatalysts. (a) CN nanotubes; (b) $\mathrm{CN}$ nanosheets; (c) this work-CN; (d) g- $\mathrm{C}_{3} \mathrm{~N}_{4}$.

materials [55-57].

The specific surface areas (BET) of different CN photocatalysts were further investigated using the nitrogen adsorption-desorption isotherms shown in Fig. 6. The surface area of the prepared $\mathrm{CN}$ reached $42.8 \mathrm{~m}^{2} \mathrm{~g}^{-1}$, which was more than 8.7 times that of $\mathrm{g}-\mathrm{C}_{3} \mathrm{~N}_{4}\left(4.9 \mathrm{~m}^{2} \mathrm{~g}^{-1}\right)$. The surface area of $\mathrm{CN}$ nanotubes was $37.5 \mathrm{~m}^{2} \mathrm{~g}^{-1}$ and that of $\mathrm{CN}$ nanosheets was $10.8 \mathrm{~m}^{2}$ $\mathrm{g}^{-1}$. The higher specific surface area of the prepared CN photocatalysts led to many more active sites [58,59].

Based on elemental analyses via the XPS spectra shown in Fig. 7, the $\mathrm{C} / \mathrm{N}$ molar ratios of different $\mathrm{CN}$ photocatalysts were 2.86:1 (CN nanotubes), 0.87:1 (CN nanosheets) and 0.81:1 (this work-CN). The peaks in the N1s spectra (Fig. 7(b), (d), and (f)) were caused by $s p^{2}$ hybridizations $\left(\mathrm{C}-\mathrm{N}-\mathrm{H}, \mathrm{N}(-\mathrm{C})_{3}\right.$, and $\mathrm{C}=\mathrm{N}-\mathrm{C}$ at approximately 400.4, 398.7, and 398.4 eV, respectively) [60].

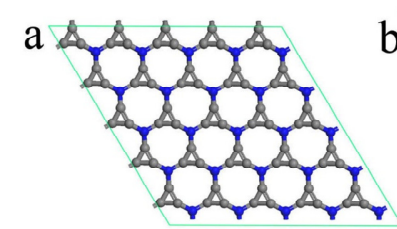

C
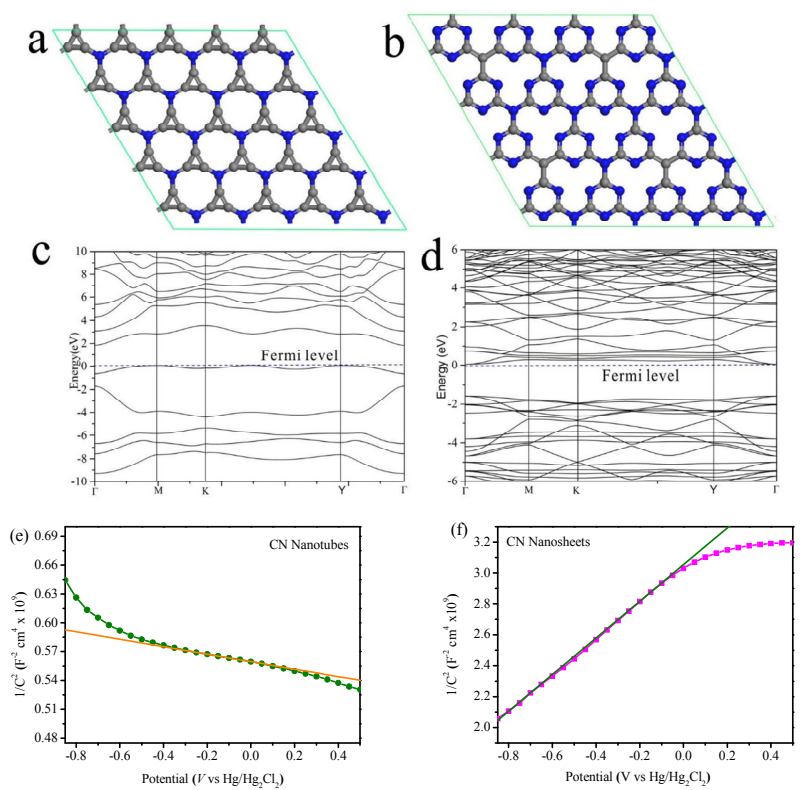

Fig. 8. Optimized structures of $\mathrm{C}_{2.83} \mathrm{~N}$ (a) and $\mathrm{C}_{0.82} \mathrm{~N}$ (b); carbon atoms are gray and nitrogen atoms are blue. Electronic band structures of $\mathrm{C}_{2.83} \mathrm{~N}\left(\mathrm{c}\right.$ ) and $\mathrm{C}_{0.82} \mathrm{~N}(\mathrm{~d})$. The energy at the Fermi level was set to zero. (e f) Mott-Schottky plots for determining $\mathrm{CN}$ nanotubes and nanosheets.

Moreover, the elemental analyzer was typically used to determine the molar ratio of $\mathrm{C} / \mathrm{N}$. The $\mathrm{C} / \mathrm{N}$ molar ratios were 2.83:1 (CN nanotubes), 0.82:1 (CN nanosheets), and 0.78:1 (this work-CN). Because XPS is surface-sensitive technology, the carbon content of the prepared $\mathrm{CN}$ surface was low by roasting. Therefore, the results of the elemental analysis of $\mathrm{C} / \mathrm{N}$ were relatively accurate $[33,58]$.

Modeling and calculations based on the first principle are shown in Fig. 8, and they were performed in accordance with the $\mathrm{C} / \mathrm{N}$ element ratio. When the $\mathrm{C} / \mathrm{N}$ molar ratio was 2.83:1
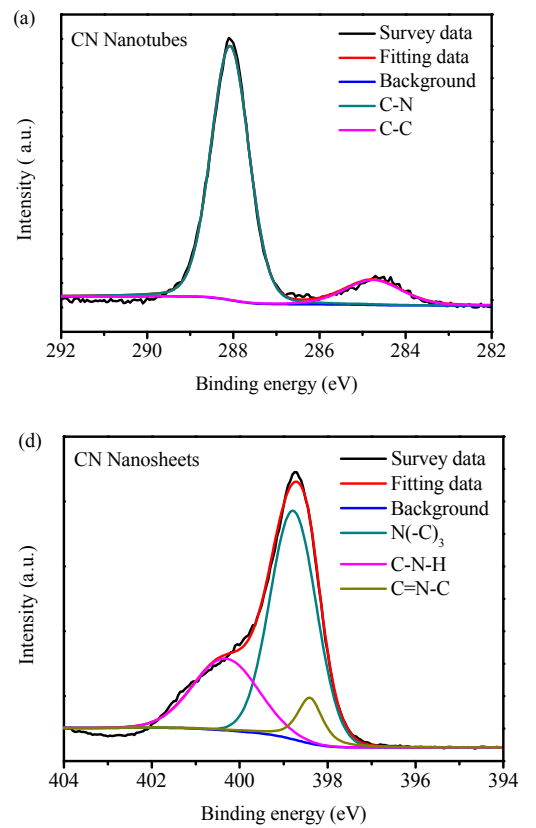
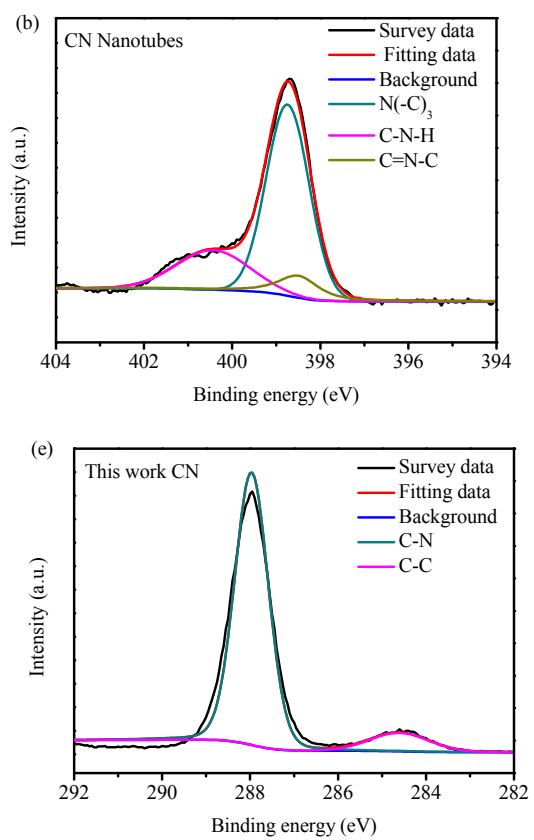
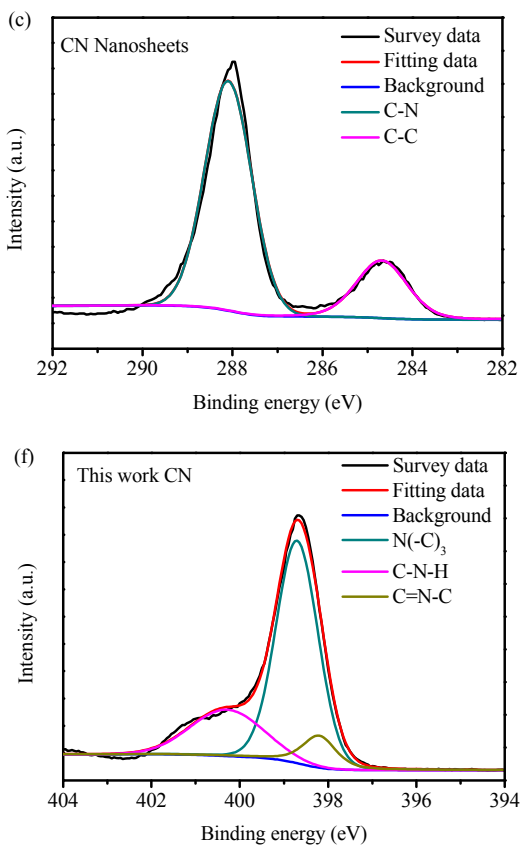

Fig. 7. High-resolution XPS spectra of different $\mathrm{CN}$ photocatalysts. (a, c, e) C1s; (b, d, f) N1s. 

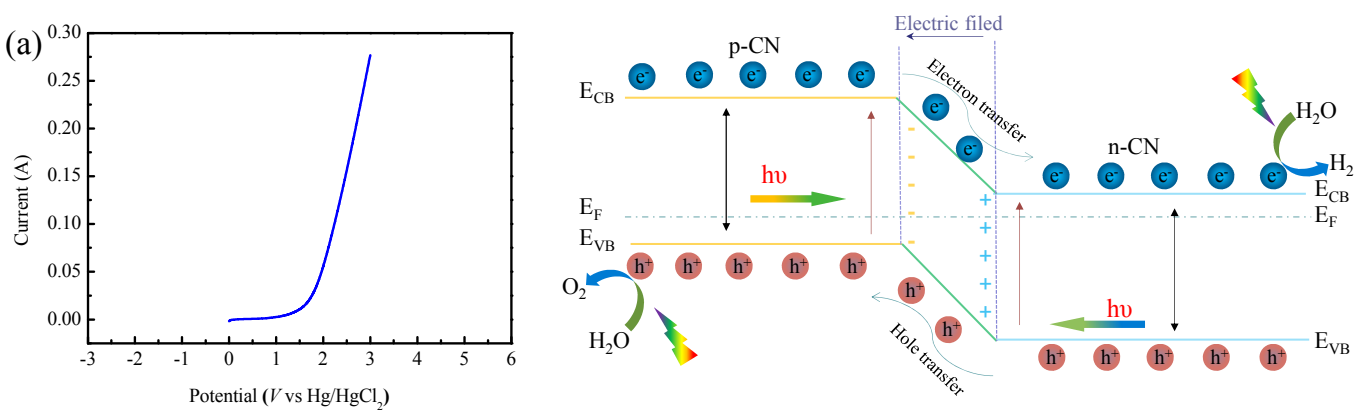

Fig. 9. (a) Characteristic current-voltage curve of CN (this work). (b) Schematic diagram showing the production of hydrogen and oxygen, energy band structure, and electron-hole pair separation in this $\mathrm{CN}$ photocatalyst containing a p-n heterojunction.

(Fig. 8(a)), the Fermi level approached the valence band (Fig. 8(c)), indicating that $\mathrm{CN}$ might contain a p-type structure. When the molar ratio of $\mathrm{C} / \mathrm{N}$ was 0.82:1 (Fig. 8(b)), the Fermi level approached the conduction band (Fig. 8(d)), suggesting that this CN might contain an n-type structure. Impedance spectroscopy at an alternating current frequency of $1 \mathrm{kHz}$ afforded the Mott-Schottky diagrams shown in Fig. 8(e) and 8(f). The slope of the Mott-Schottky curve indicated the type of semiconductor to which the material belonged [60-63]. Generally, the slope of the curve of $C_{x} N_{y}$ materials is positive; a positive slope suggests that the material is an n-type semiconductor. However, the $\mathrm{CN}$ nanotubes prepared in this way contained a p-type structure, and the slope of the Mott-Schottky curve was negative (Fig. 8(e)), which was a new discovery. Moreover, CN (nanosheets) containing an n-type structure were also prepared via the above method. As shown in Fig. 8(f), the Mott-Schottky curve of the n-type CN material had a positive slope with electrons as most carriers [64-66].

We attempted to prove that there was a small p-n junction structure in $\mathrm{CN}$ (this work) after compounding $\mathrm{CN}$ nanotubes (containing a p-type structure) and $\mathrm{CN}$ nanosheets (containing an n-type structure). The current-voltage curve of $\mathrm{CN}$ (this work) is shown in Fig. 9(a). When the reverse voltage was increased to the breakdown voltage value, the current instantly increased, indicating that the $p-n$ junction contained in this $\mathrm{CN}$ was broken down, which is a typical p-n junction characteristic. Therefore, this $\mathrm{CN}$ photocatalyst contained a certain size of a p-n junction structure. As shown in Fig. 9(b), preparing a photocatalyst with a p-n heterojunction led to highly efficient charge collection and separation [67-69]. In this structure, there was an internal electric field, which could cause the photocatalyst to generate electrons and charges under very low light intensity [70-72]. The photogenerated electrons were transferred to the n-type $\mathrm{CN}$ conduction band and reduced with water to generate hydrogen. Additionally, the photogenerated charges shifted to the p-type $\mathrm{CN}$ valence band and were oxidized with water to convert into oxygen. Therefore, under the same light intensity, the $\mathrm{CN}$ photocatalyst that contained the p-n heterojunction could generate more electrons and holes, greatly improving its activity and efficiency. The photocatalytic efficiency of $\mathrm{CN}$ was much higher than those of $\mathrm{CN}$ nanotubes and nanosheets.

\section{Conclusions}

$\mathrm{CN}$ photocatalysts with heterogeneous structures were successfully synthesized via a clever design for the first time. Benefitting from the interface interactions in hybrid architectures, the CN photocatalysts exhibited high photocatalytic activity. The hydrogen production rate of these $\mathrm{CN}$ photocatalysts reached $17028.82 \mu \mathrm{molh}^{-1} \mathrm{~g}^{-1}$, the AQE was $11.2 \%$ at $420 \mathrm{~nm}$, and the lifetime of the charge carriers causing the fluorescence of CN reached 9.99 ns. Significantly, the CN photocatalysts displayed satisfactory results in overall water splitting without the addition of sacrificial agents. The average hydrogen and oxygen production rates were 270.95 and $115.21 \mu$ molh $^{-1} \mathrm{~g}^{-1}$ in $7 \mathrm{~h}$, respectively. Furthermore, the structural model was established and discussed via first principles, and the Mott-Schottky plot and current-voltage curve were fabricated via electrochemical tests. This CN photocatalyst had a small p-n junction in its heterogeneous structure, which further enhanced its photocatalytic efficiency. Therefore, this work can promote the development of $\mathrm{CN}$ photocatalysts.

\section{Appendix A. Supplementary material}

Supplementary data associated with this article can be found in the online version.

\section{References}

[1] G. Zhang, G. Li, T. Heil, S. Zafeiratos, A. Savateev, X. Wang, M. Antonietti, Angew. Chem. Int. Ed., 2019, 58, 3433-3437.

[2] Y. Li, T. Kong, S. Shen, Small, 2019, 15, 1900772.

[3] I. Y. Kim, S. Kim, X. Jin, S. Premkumar, G. Chandra, N. Lee, G. P. Mane, S. Hwang, S. Umapathy, A. Vinu, Angew. Chem. Int. Ed., 2018, 57, 17135-17140.

[4] Y. P. Pang, M. N. Uddin, W. Chen, S. Javaid, E. Barker, Y. G. Li, A. Suvorova, M. Saunders, Z. Y. Yin, G. H. Jia, Adv. Mater., 2019, 31, 1905540.

[5] G. Zhang, L. Lin, G. Li, Y. Zhang, A. Savateev, S. Zafeiratos, X. Wang, M. Antonietti, Angew. Chem. Int. Ed., 2018, 57, 9372-9376.

[6] G. H. Jia, Y. P. Pang, J. J. Ning, U. Banin, B. T. Ji, Adv. Mater., 2019, 31, 1900781.

[7] Z. Wang, Y. Inoue, T. Hisatomi, R. Ishikawa, Q. Wang, T. Takata, S. 
Chen, N. Shibata, Y. Ikuhara, K. Domen, Nat. Catal., 2018, 1, 756-763.

[8] D. C. Chen, H. Y. Zhang, Y. G. Li, Z. Y. Yin, H. Q. Sun, L. C. Zhang, S. B. Wang, M. Saunders, E. Barker, G. H. Jia, Adv. Mater., 2018, 30, 1803351.

[9] Y. J. Ren, D. Q. Zeng, W. J. Ong, Chin. J. Catal., 2019, 40, 289-319.

[10] Q. Wang, T. Hisatomi, Q. Jia, H. Tokudome, M. Zhong, C. Wang, Z. Pan, T. Takata, M. Nakabayashi, N. Shibata, Y. Li, I. Sharp, A. Kudo, T. Yamada, K. Domen, Nat. Mater., 2016, 15, 611-615.

[11] X. Wang, K. Maeda, A. Thomas, K. Takanabe, G. Xin, J. M. Carlsson, K. Domen, M. Antonietti, Nat. Mater., 2009, 8, 76-80.

[12] Y. Kang, Y. Yang, L. Yin, X. Kang, L. Wang, G. Liu, H. Cheng, Adv. Mater., 2016, 28, 6471-6477.

[13] Y. Zheng, L. Lin, B. Wang, X. Wang, Angew. Chem. Int. Ed., 2015, 54, 12868-12884.

[14] R. C. Shen, J. Xie, Q. J. Xiang, X. B. Chen, J. Z. Jiang, X. Li, Chin. J. Catal, 2019, 40, 240-288.

[15] X. Li, W. Bi, L. Zhang, S. Tao, W. Chu, Q. Zhang, Y. Luo, C. Wu, Y. Xie, Adv. Mater., 2016, 28, 2427-2431.

[16] H. Q. Xu, J. Hu, D. Wang, Z. Li, Q. Zhang, Y. Luo, S. H. Yu, H. L. Jiang, J. Am. Chem. Soc., 2015, 137, 13440-13443.

[17] D. Ren, W. Zhang, Y. Ding, R. Shen, Z. Jiang, X. Lu, X. Li, Sol. RRL., 2020, doi:10.1002/solr.201900423.

[18] X. She, J. Wu, H. Xu, J. Zhong, Y. Wang, Y. Song, K. Nie, Y. Liu, Y. Yang, M. T. F. Rodrigues, R. Vajtai, J. Lou, D. Du, H. Li, P. M. Ajayan, Adv. Energy Mater., 2017, 7, 1700025.

[19] S. Cao, J. Low, J. Yu, M. Jaroniec, Adv. Mater., 2015, 27, 2150-2176.

[20] N. Xiao, S. S. Li, S. Liu, B. R. Xu, Y. D. Li, Y. Q. Gao, L. Ge, G. W. Lu, Chin. J. Catal, 2019, 40, 352-361.

[21] J. Mahmood, E. K. Lee, M. Jung, D. Shin, H. J. Choi, J. M. Seo, S. M. Jung, D. W. Kim, F. Li, M. S. Lah, N. Park, H. J. Shin, J. H. Oh, J. B. Baek, Proc. Natl. Acad. Sci. USA, 2016, 113, 7414-7419.

[22] J. Q. Wen, J. Xie, X. B. Chen, X. Li, Appl. Surf. Sci., 2017, 391, 72-123.

[23] J. Mahmood, Lee, K. E. M. Jung, D. Shin, I. Y. Jeon, S. M. Jung, H. J. Choi, J. M. Seo, S. Y. Bae, S. D. Sohn, N. Park, J. H. Oh, H. J. Shin, J. B. Baek, Nat. Commun., 2015, 6, 6486.

[24] C. Y. Wen, J. Tersoff, K. Hillerich, M. C. Reuter, J. H. Park, S. Kodambaka, E. A. Stach, F. M. Ross, Phys. Rev. Lett., 2011, 107, 025503.

[25] M. Z. Rahman, J. Moffatt, N. A. Spooner, Mater. Horiz., 2018, 5, 553-559.
[26] D. Tsivion, M. Schvartzman, R. Popovitz-Biro, P. von Huth, E. Joselevich, Science, 2011, 333, 1003-1007.

[27] J. Zhang, L. Qi, J. Ran, J. Yu, S. Qiao, Adv. Energy Mater., 2014, 4, 1301925.

[28] Y. Pei, H. Wang, G. J. Snyder, Adv. Mater., 2012, 24, 6125-6135.

[29] X. B. Huang, Z. Y. Wu, H. Y. Zheng, W. J. Dong, G. Wang, Green Chem., 2018, 20, 664-670.

[30] F. K. Kessler, Y. Zheng, D. Schwarz, C. Merschjann, W. G. Schnick, X. Wang, M. J. Bojdys, Nat. Rev. Mater., 2017, 2, 17030.

[31] G. X. Zhao, G. G. Liu, H. Pang, H. M. Liu, H. B. Zhang, K. Chang, X. G. Meng, X. J. Wang, J. H. Ye, Small, 2016, 12, 6160-6166.

[32] J. V. Holm, H. I. Jørgensen, P. Krogstrup, J. Nygård, H. Liu, M. Aagesen, Nat. Commun., 2013, 4, 1498.

[33] G. Zhang, G. Li, Z. Lan, L. Lin, A. Savateev, T. Heil, S. Zafeiratos, X. Wang, M. Antonietti, Angew. Chem. Int. Ed., 2017, 56, 13445-13449.

[34] Y. Sakurai, A. A. Kolokoltsov, C.-C. Chen, M. W. Tidwell, W. E. Bauta, N. Klugbauer, C. Grimm, C. Wahl-Schott, M. Biel, R. A. Davey, Science, 2015, 347, 995-998.

[35] D. J. Martin, K. Qiu, S. A. Shevlin, A. D. Handoko, X. Chen, Z. Guo, J. Tang, Angew. Chem. Int. Ed., 2014, 53, 9240-9245.

[36] X. H. Li, J. S. Zhang, X. F. Chen, A. Fischer, A. Thomas, M. Antonietti, X. C. Wang, Chem. Mater., 2011, 23, 4344-4348.

[37] G. Liu, T. Wang, H. Zhang, X. Meng, D. Hao, K. Chang, P. Li, T. Kako, J. Ye, Angew. Chem. Int. Ed., 2015, 54, 13561-13565.

[38] Q. Liang, Z. Li, X. Yu, Z. Huang, F. Kang, Q. H. Yang, Adv. Mater., 2015, 27, 4634-4639.

[39] Z. Li, Y. N. Ma, X. Y. Hu, E. Z. Liu, J. Fan, Chin. J. Catal., 2019, 40, 434-445.

[40] N. P. Dasgupta, J. Sun, C. Liu, S. Brittman, S. C. Andrews, J. W. Lim, H. Gao, R. Yan, P. Yang, Adv. Mater., 2014, 26, 2137-2184.

[41] M. Shalom, S. Inal, C. Fettkenhauer, D. Neher, M. Antonietti, J. Am. Chem. Soc., 2013, 135, 7118-7121.

[42] J. X. Sun, Y. P. Yuan, L. G. Qiu, X. Jiang, A. J. Xie, Y. H. Shen, J. F. Zhu, Dalton Trans., 2012, 41, 6756-6763.

[43] G. Zhao, Y. Cheng, Y. Wu, X. Xu, X. Hao, Small, 2018, 14, 1704138.

[44] H. Huang, K. Xiao, N. Tian, F. Dong, T. Zhang, X. Du, Y. Zhang, J. Mater. Chem. A, 2017, 5, 17452-17463.

[45] L. Lin, H. Ou, Y. Zhang, X. Wang, ACS Catal., 2016, 6, 3921-3931.

[46] Y. S. Jun, E. Z. Lee, X. Wang, W. H. Hong, G. D. Stucky, A. Thomas, Adv. Funct. Mater., 2013, 23, 3661-3667.

[47] Y. Cui, Z. Ding, X. Fu, X. Wang, Angew. Chem. Int. Ed., 2012, 51,

\section{Graphical Abstract}

Chin. J. Catal., 2021, 42: 501-509 doi: 10.1016/S1872-2067(20)63670-1

\section{Design of p-n homojunctions in metal-free carbon nitride} photocatalyst for overall water splitting

Gang Zhao, Shuhua Hao, Jinghua Guo, Yupeng Xing, Lei Zhang, Xijin Xu*

University of Jinan; Shandong University

In this work, we successfully prepared a $\mathrm{CN}$ material with a heterogeneous structure via a clever design for the first time. Benefitting from the interface interactions in hybrid architectures, the CN photocatalysts exhibited high photocatalytic activity.

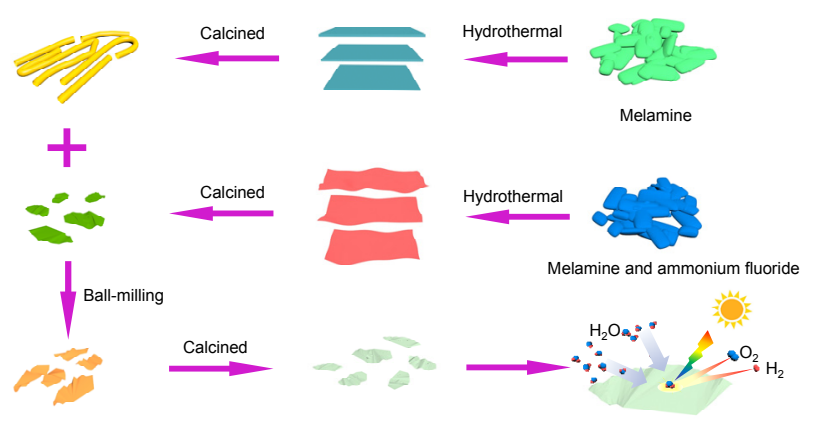


11814-11818.

[48] Q. Liu, X. Wang, Q. Yang, Z. Zhang, X. Fang, Appl. Catal. B, 2018, $225,22-29$.

[49] J. W. Zhang, S. Gong, N. Mahmood, L. Pan, X. Zhang, J. Zou, Appl. Catal. B, 2018, 221, 9-16.

[50] Z. Lin, X. Wang, ChemSusChem, 2014, 7, 1547-1550.

[51] J. Zhang, M. Zhang, C. Yang, X. Wang, Adv. Mater., 2014, 26, 4121-4126.

[52] J. Sun, J. Zhang, M. Zhang, M. Antonietti, X. Fu, X. Wang, Nat. Commun., 2012, 3, 2152.

[53] G. Zhao, T. Wang, Y. Shao, Y. Wu, B. Huang, X. Hao, Small, 2017, 13, 1602243.

[54] Z. Lin, X. Wang, Angew. Chem. Int. Ed., 2013, 52, 1735-1738.

[55] M. Z. Rahman, C. B. Mullins, Acc. Chem. Res., 2019, 52, 248-257.

[56] M. Z. Rahman, Y. Tang, P. Kwong, Appl. Phys. Lett., 2018, 112, 253902.

[57] M. Z. Rahman, K. Davey, Phys. Rev. Mater., 2018, 2, 125402.

[58] G. Zhang, G. Li, Z. Lan, L. Lin, A. Savateev, T. Heil, S. Zafeiratos, X. Wang, M. Antonietti, Angew. Chem. Int. Ed., 2017, 56, 13445-13449.

[59] N. Tian, Y. Zhang, X. Li, K. Xiao, X. Du, F. Dong, G. I. N. Waterhouse, T. Zhang, H. Huang, Nano Energy, 2017, 38, 72-81.

[60] M. Z. Rahman, P. C. Tapping, T. W. Kee, R. Smernik, N. Spooner, J.
Moffatt, Y. Tang, K. Davey, S. Qiao, Adv. Funct. Mater., 2017, 27, 1702384.

[61] F. Dong, Z. Zhao, T. Xiong, Z. Ni, W. Zhang, Y. Sun, W. K. Ho, ACS Appl. Mater. Interfaces, 2013, 5, 11392-11401.

[62] X. Li, J. G. Yu, M. Jaroniec, X. B. Chen, Chem. Rev., 2019, 119, 3962-4179.

[63] M. Rahman, K. Davey, S. Z. Qiao, Small, 2017, 13, 1700376.

[64] Y. B. Li, Z. L. Jin, L. J. Zhang, K. Fan, Chin. J. Catal., 2019, 40, 390-402.

[65] M. Z. Rahman, K. Davey, S. Z. Qiao, J. Mater. Chem. A, 2018, 6, 1305-1322.

[66] M. Z. Rahman, C. B. Mullins, K. Davey, Adv. Sci., 2018, 5, 1800820.

[67] D. Ren, Z. Liang, Y. H. Ng, P. Zhang, Q. Xiang, X. Li, Chem. Eng. J., 2020, 390, 124496.

[68] H. Wang, L. Zhang, Z. Chen, J. Hu, S. Li, Z. Wang, J. Liu, X. Wang, Chem. Soc. Rev., 2014, 43, 5234-5244.

[69] S. Javaid, X. J. Li, F. Wang, W. Chen, S. B. Wang, G. H. Jia, F. Jones, J. Mater. Chem. C, 2019, 7, 14517.

[70] L. Jiang, G. Zhou, J. Mi, Z. Wu, Catal. Commun., 2012, 24, 48-51.

[71] G. Zhao, Y. L. Cheng, P. X. Sun, W. X. Ma, S. H. Hao, X. K. Wang, X. J. Xu, Q. Q. Xu, M. Q. Liu, Electrochim. Acta, 2020, 331, 135262.

[72] W. Chen, X. J. Li, F. Wang, S. Javaid, Y. P. Pang, J. Y. Chen, Z. Y. Yin, S. B. Wang, Y. G. Li, G. H. Jia, Small, 2020, 16, 1902231.

\title{
设计 $\mathbf{p - n}$ 同质结构实现碳氮光催化剂的全解水性能
}

\author{
赵 刚 ${ }^{\mathrm{a}, \dagger}$ ，郝树华 $\mathrm{a}, \dagger$ ，郭静华 ${ }^{\mathrm{a}}$ ，邢钰鹏 ${ }^{\mathrm{a}}$, 张 雷 ${ }^{\mathrm{b}}$, 徐锡金 ${ }^{\mathrm{a},{ }^{*}}$ \\ a济南大学物理科学与技术学院, 功能微纳材料与器件实验室, 山东济南 250022 \\ $\mathrm{b}$ 山东大学晶体功能材料国家重点实验室, 山东济南250100
}

\begin{abstract}
摘要: 非金属氮化碳 $(\mathrm{CN})$ 因其独特的光催化性能而备受关注. 本文利用水热处理、高温烧结、高能球磨和烧结的方法成功 制得一种具有混合结构的 $\mathrm{CN}$ 光催化剂. 先以三聚氧胺为原料进行水热处理 $\left(180^{\circ} \mathrm{C}, 24 \mathrm{~h}\right)$, 过滤干燥后, 转移到高纯氞气保 护下的管式炉中, 于 $550^{\circ} \mathrm{C}$ 处理 $1 \mathrm{~h}$ 得到 $\mathrm{CN}$ 材料. 然后将 $\mathrm{CN}$ 用三聚氧胺和氟化铵水热 $180^{\circ} \mathrm{C}$ 处理 $24 \mathrm{~h}$, 过滤、干燥、煅烧 $(550$ ${ }^{\circ} \mathrm{C}, 1 \mathrm{~h}$ )得到第二种材料. 最后将其与 $\mathrm{CN}$ 材料按等比例混合, 经高能球磨研磨, 再于管式炉中在气氛保护下淬火, 得到最终 催化剂样品. 由于这种结构的界面作用, 使 CN光催化剂显示出了高的光催化活性. 它的产氢效果可以高达 $17028.82 \mu \mathrm{mol}$ $\mathrm{h}^{-1} \mathrm{~g}^{-1}$, 在 $420 \mathrm{~nm}$ 光照下, 其光量子效率也达到 $11.2 \%$. 随后, 采用纳秒级别的时间分辨萤光(PL)光谱测得其苂光寿命为 9.9 ns. 有助于电子与空穴参与反应更有趣的是, 在不加牺牲剂时, 该光催化剂具有高效的全解水效果, 其产氢效率为 270.95 $\mu \mathrm{mol} \mathrm{h} \mathrm{h}^{-1} \mathrm{~g}^{-1}$, 产氧效率为 $115.21 \mu \mathrm{mol} \mathrm{h}^{-1} \mathrm{~g}^{-1}$, 有望实际用于全解水反应中. 另外, 通过紫外可见漫反射光谱, PL光谱和材料 的比表面等测试来考察该 $\mathrm{CN}$ 光催化剂效果好的原因. 发现该材料具有更高比表面积有更多活性点参与反应. 同时, 通过 电化学测试获得了肖特基曲线和电流-电压曲线, 发现该光催化剂里含有少量的pn结构, 这种结构使材料在弱光下也会产 生光生载流子, 实际上它是起到光生载流子的激发作用, 即在相同光照下, 就会产生更多的光生载流子数量, 从而进一步提 高了其催化效果. 因此, 本工作对优化碳氮光催化剂的催化效果有很好的指导意义.
\end{abstract}

关键词: 二维非金属光催化剂; 氮化碳; 全解水; 时间分辨光谱; 密度泛函理论; 多相结构

收稿日期: 2020-05-21. 接受日期: 2020-06-27. 出版日期: 2021-03-05.

*通讯联系人. 电话/传真: (0531)82769995; 电子信箱: sps_xuxj@ujn.edu.cn

†共同第一作者.

基金来源：国家自然科学基金(51802177，51672109，11504134); 山东省自然科学基金重大基础研究项目(ZR2018ZC0842); 山东 省自然科学基金(ZR2018BEM019).

本文的电子版全文由Elsevier出版社在ScienceDirect上出版(http://www.sciencedirect.com/science/journal/18722067). 